\title{
Multinucleated normoblastemia in a newborn secondary to hypoxia
}

\author{
Gozdem Kayki, M.D. ${ }^{a}$, Davut Bozkaya, M.D. ${ }^{b}$, Melek Buyukeren, M.D. ${ }^{b}$, Betul Tavil, M.D. ${ }^{c}$ and Sule Yigit, M.D. ${ }^{b}$
}

\begin{abstract}
Normoblasts may be seen in peripheral blood smear of newborns. The number of normoblasts per 100 white blood cells is generally in the range of $0-10$.They can be seen more common than usual in hypoxic condition, because intrauterine hypoxia increases the production of red blood cells. However, multinucleated normoblasts in a newborn caused by hypoxia haven't been reported before. We present a newborn with multinucleated normoblasts secondary to intrauterine hypoxia. This case is important; because it is the first time multinucleated normoblasts in peripheral blood smear of a hypoxic newborn has been detected.
\end{abstract}

Key words: multinucleated normoblasts, hypoxia, newborn.

http: / / dx.doi.org/10.5546/ aap.2017.eng.e217

To cite: Kayki G, Bozkaya D, Buyukeren M, et al. Multinucleated normoblastemia in a newborn secondary to hypoxia. Arch Argent Pediatr 2017;115(4):e217-e219.

\section{INTRODUCTION}

Normoblast is a precursor in erythroid series. These nucleated red blood cells can be seen in peripheral blood smear of newborns. ${ }^{1}$ The number of normoblasts per 100 white blood cells is generally in the range of $0-10 .^{2,3}$ If there is a hypoxic condition, normoblast count may be higher than 10, because hypoxia is the major regulator of production of red blood cells (RBCs). ${ }^{2,4}$

a. Department of Pediatrics, Hacettepe University Faculty of Medicine, Turkey.

b. Division of Neonatology, Department of Pediatrics, Hacettepe University Faculty of Medicine, Turkey.

c. Division of Pediatric Hematology, Department of Pediatrics, Hacettepe University Faculty of Medicine, Turkey.

E-mail Address:

Gozdem Kayki, M.D. gozdemkayki@hotmail.com

Funding: None.

Conflict of interest: None.

Received: 5-27-2016

Accepted: 2-20-2017
Multinucleated normoblasts have been demonstrated in bone narrow aspiration smears of patients with congenital dyserythropoietic anemia (CDA) type II and type III; in peripheral blood smear of a patient with CDA type II. ${ }^{5}$ Multinucleated normoblasts can also be seen in myelodysplasia and erythroleukemia. ${ }^{5}$ However, hypoxia hasn't been presented as a reason of multinucleated normoblasts until now. Here, we report this case of multinucleated normoblastemia of a newborn secondary to hypoxia.

\section{CASE REPORT}

Following an uneventful pregnancy, a full-term (38 weeks), male infant was born by spontaneous vaginal delivery to a 38 -yearold gravida 4, para 4 mother. Umbilical cord had wrapped around his neck on the delivery. Apgar scores were 6 and 9 at 1 and 5 minutes. Amniotic fluid was clear. Birth weight was $3900 \mathrm{~g}$. The baby presented with tachypnea and poor sucking at $6^{\text {th }}$ hour of his life. Blood sample was taken. In automated complete blood count, his hemoglobin $(\mathrm{Hb})$ was $19 \mathrm{~g} / \mathrm{dL}$; white blood cell count, $96.5 \times 10^{9} / \mathrm{L}$; and platelets count, $55 \times 10^{9} / \mathrm{L}$. The baby was referred from a local hospital because of probable leukemia and was admitted to the neonatal intensive care unit of our hospital.

On admission, the vital signs were normal. Physical examination revealed dry skin, widespread desquamation, decreased subcutaneous fat, subconjuctival hemorrhage, and liver 2-cm below right costal margin. His complete blood count analysis showed: Hb $18.5 \mathrm{~g} / \mathrm{dL}$; white blood cell count, $79 \times 10^{9} / \mathrm{L}$; and platelet count, $50 \times 10^{9} / \mathrm{L}$. In his peripheral blood smear; the number of normoblasts was 360 per 100 white blood cells. Most of these normoblasts were binucleated or multinucleated (Figure 1). The real leukocyte count was approximately $17 \times 10^{9} / \mathrm{L}$; the presence of numerous normoblasts have increased the white blood cell count in automated complete blood count analyzer. The biochemical markers were: total bilirubin/direct bilirubin was $13.1 / 0.7 \mathrm{mg} / \mathrm{dL}$; blood urea nitrogen, $13.8 \mathrm{mg} /$ $\mathrm{dL}$, and creatinine, $1.7 \mathrm{mg} / \mathrm{dL}$. Venous blood gas analysis revealed that $\mathrm{pH}$ was $7.24 ; \mathrm{pCO}_{2}$, $34 \mathrm{mmHg}$; $\mathrm{pO}_{2^{\prime}} 40 \mathrm{mmHg}$; and $\mathrm{HCO}_{3^{\prime}} 17 \mathrm{mmol} / \mathrm{L}$. 
There wasn't any ABO incompatibility and direct Coombs test was negative.

Oral feeding and intravenous hydration were administered to the baby. On the $2^{\text {nd }}$ day of hospitalization the baby received phototherapy when total bilirubin level was $15.6 \mathrm{mg} / \mathrm{dL}$. On the $5^{\text {th }}$ day of hospitalization, blood urea nitrogen and creatinine levels became to normal values. Blood urea nitrogen decreased to 3.1 $\mathrm{mg} / \mathrm{dL}$ and creatinine decreased to $0.59 \mathrm{mg} / \mathrm{dL}$. Then, the intravenous hydration support was stopped. Abdominal and cranial ultrasounds were performed by a radiologist and evaluated as normal. Baby's activity and sucking became much better day-by-day. On the $10^{\text {th }}$ day of hospitalization, normoblast counted was 2 per 100 white blood cells in peripheral blood smear (Table 1). On the $15^{\text {th }}$ day, the baby was discharged. There was no information about his follow-up.

\section{DISCUSSION}

Normoblasts can be seen in a range of $0-10$ for every $100 \mathrm{WBC}$ in peripheral blood smear in newborns during the first 5 days of their life. ${ }^{1}$ Due to the immaturity of reticuloendothelial system, hyposplenism may occur in neonatal period. Generally, normoblasts in circulation, which leak from bone narrow, are cleared in spleen. That's the reason why normoblasts can be seen in peripheral blood smears of newborns. ${ }^{1}$

FIGURE 1. Multinucleated normoblasts in pheripheral blood smear

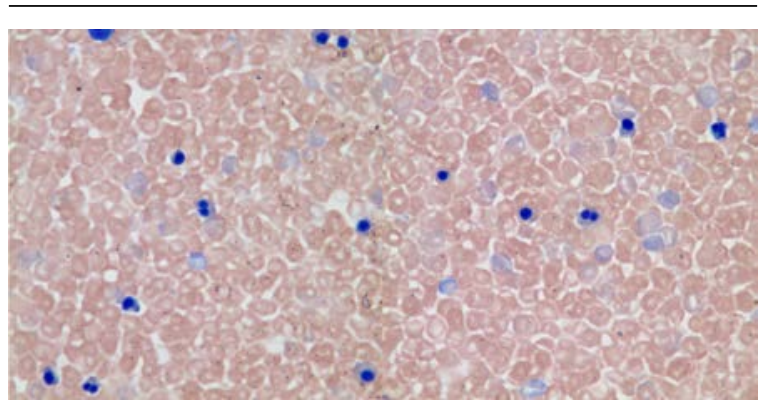

Furthermore, if cellular components increase, the capacity of spleen is overcomed and normoblasts can be seen more than usual in peripheral blood smears. ${ }^{1}$ In conditions with an increase in production of erythroid precursors including maternal diabetes mellitus, intrauterine growth retardation, and hypoxia; normoblast count can be more than 10 for every $100 \mathrm{WBC} .^{1-3}$

At hypoxia, depending on the decrease of oxygen content in tissues, erytropoetin increases for red blood cell production. Therefore; high erytropoetin levels result in elevated production of erytroblasts in bone narrow and there can be more normoblasts in pheripheral blood smear. ${ }^{6}$ Previous studies showed that normoblasts could be a marker of fetal hypoxia. ${ }^{2,3,7,8}$ According to the study reported by Fox $\mathrm{H}$ et al., there can be a relationship with normoblast count and duration of hypoxia. ${ }^{7}$ In case of a short duration of hypoxia, there can not be enough time to increase normoblast production. ${ }^{7}$ The time between the increase of erythropoietin caused by hypoxia and the appearance of normoblasts should be at least 36-48 hours. ${ }^{9}$ Therefore, in our case, very high levels of normoblasts may be explained not only by acute hypoxia due to wrapping of the cordon, but also by intrauterine chronic hypoxia. The findings of dysmaturity also supported this idea, because intrauterine hypoxia is known a cause of dysmaturity. ${ }^{4}$

The distinctive feature of this case is the presence of multinucleated normoblasts in peripheral blood smear. Multinucleated normoblasts have also been demonstrated in patients with congenital dyserytropoetic anemia tip II and type III. ${ }^{10}$ Normocytic mild anemia, jaundice, splenomegaly, or hepatomegaly is typically seen in patients with CDA type II. ${ }^{5}$ Liljeholm et al., have shown failure of cytokinesis occurs due to KIF23 gene mutation in CDA type III, ${ }^{11}$ and KIF23 gene encodes a protein that regulates cell separation during mitosis. ${ }^{5}$ Therefore multinucleated normoblasts can be seen in patients with CDA type III. ${ }^{11}$ Diagnoses of CDA type II and III are generally made later in life, because their symptoms are milder. Besides,

TABLE 1. Normoblast and WBC count in automated complete blood count analyzer

\begin{tabular}{lccccc}
\hline & $\mathbf{1}^{\text {st }}$ day & $\mathbf{2}^{\text {nd }}$ day & $\mathbf{4}^{\text {th }}$ day & $\mathbf{5}^{\text {th }}$ day & $\mathbf{1 0}^{\text {th }}$ day \\
\hline Normoblast count (per 100 WBC) & 360 & 320 & 340 & 280 & 2 \\
WBC count in automated complete blood count analyzer (x10 $/ \mathrm{L})$ & 79,3 & 54,4 & 42,7 & 26,9 & 12 \\
\hline
\end{tabular}


erythroleukemia and myelodysplasia maybe other reasons of multinucleated normoblasts. ${ }^{5}$ However, our case could not be explained by these conditions. If dyserythropoiesis was the reason for multinucleated normoblasts, decreased hemoglobin level and anemia would be seen. However, hemoglobin levels of our patient were always in a normal range. Moreover, the patient's symptoms that began in neonatal period were transient; which was not suggestive for CDA type II or III. The reason of multinuclearity may be the increase in production of erythroblasts secondary to hypoxia. For the first time, multinucleated normoblasts have been shown secondary to hypoxia. It seems reasonable to assume that chronic hypoxia and additional acute hypoxia due to cordon wrapping may be the cause for multinucleated normoblasts seen in our patient's peripheral blood smears.

\section{REFERENCES}

1. Constantino BT, Cogionis B. Nucleated RBCs-Significance in the peripheral blood film. Lab Med 2000;31(4):223-9.

2. Phelan JP, Ahn MO, Korst LM, et al. Nucleated red blood cells: a marker for fetal asphyxia? Am J Obstet Gynecol 1995;173(5)1380-4.

3. Korst LM, Phelan JP, Ahn MO, et al. Nucleated red blood cells: an update on the marker for fetal asphyxia. Am J Obstet Gynecol 1996;175(4 Pt 1):843-6.

4. Lanskowsky P.Polycythemia.In:Lanzkowsky P,ed.Manual of Pediatric Hematology and Oncology. $5^{\text {th }}$ ed. London: Elsevier; 2011:257-71.

5. Lerner NB. Congenital Dyserythropoietic Anemias. In: Kliegman RM, Stanton BF, St Geme JW, et al, eds. Nelson Textbook of Pediatrics. $19^{\text {th }}$ ed. Philadelphia: Elsevier Saunders; 2011:1654.

6. Soothill PW, Nicolaides KH, CampbellS. Prenatal asphyxia, hyperlacticaemia, hypoglycaemia, and erythrroblastosis in growth retarded fetuses. $\mathrm{Br}$ Med J (Clin Res Ed) 1987;294(6579):1051-3.

7. Fox $\mathrm{H}$. The incidence and significance of nucleated erythrocytes in the foetal vessels of the mature human placenta. J Obstet Gynaec Brit Commonw 1967;74(1):40-3.

8. Buonocore G, Perrone S, Gioia D, et al. Nucleated red blood cell count at birth as an index of perinatal brain damage. Am J Obstet Gynecol 1999;181(6):1500-5.

9. Bracci R, PerroneS, BuonocoreG. Redblood cell involvement in fetal/neonatal hypoxia. Biol Neonate 2001;79(3-4):210-2.

10. Fukuda MN. Congenital dyserythropoietic anaemia type II (HEMPAS) and its molecular basis. Baillieres Clin Haematol 1993;6(2):493-511.

11. Liljeholm M, Irvine AF, Vikberg AL, et al. Congenital dyserythropoietic anemia type III (CDA III) is caused by a mutation in kinesin family member, KIF23. Blood 2013;121(23):4791-9. 